\title{
A PORTRAIT OF MALE'S STRUGGLE QUALITY IN WILLIAM SOMERSET MAUGHAM'S LIZA OF LAMBETH
}

\author{
Fajar Aulia Wigayanti ${ }^{1}$, Miftachudin ${ }^{2}$ \\ Jena Mandiri Sidoarjo ${ }^{1}$, Politeknik Perkapalan Negeri Surabaya ${ }^{2}$ \\ aulia_wigay@yahoo.com ${ }^{1}$,mievt4@gmail.com ${ }^{2}$
}

\begin{abstract}
This article attempts to analyze William Somerset Maugham's novel entitled Liza of Lambeth. This novel tells about Liza who is loved by two men, Jim and Tom, who want Liza as their lover, so they make some efforts to get her. This article focuses on analyzing the male characters' struggle to attract Liza. The aims of this article are to describe the main characters'personality and to reveal the quality of the male characters' struggle in the novel. Dealing with the focus of the study, this study uses theory of character as the basic concept to lead the further analysis using existentialism theory to depict the male characters' struggle, and it is supported by theory of interpersonal attraction. For the last, the main point of this study will be directed to theory of deconstruction which reveals that everyone who works hard is not guaranteed to be a success. Furthermore, this paper also tries to reflect some points with Islamic value.
\end{abstract}

Keywords: existentialism; quality; struggle.

\section{INTRODUCTION}

Liza of Lambeth is William Somerset Maugham's first novel which was published in 1897 and it was sold out rapidly. This novel became Maugham's reason to choose a full time writer than being a doctor (Stevenson, 1967:60). In other word, the success of Liza of Lambeth became a turning point of his life to be a more successful writer.

This novel tells about Liza Kemp, an 18-years-old factory worker, one of the prettiest girls and is also illustrious enough in Vere Street, Lambeth. She lives with her widowed inebriate mother only. Liza has a close friend named Sally. There are also Jim and Tom who love Liza and fight to get her. Jim is a 40-year-old man who has a wife and also five children, while Tom is a single man. However, Liza is more attracted to Jim. Formerly they do not have bravery to come out together, but later many people around them know their clandestine affair. At the end of the story, Liza is bullied by Jim's wife until her condition is worst and finally she dies.

Maugham takes love as a grand theme for his first novel. Love is a universal theme. Every inch of the human's life will not be apart from love whether love from human to human, from human to nature, animals, plants, and so on. Therefore, love has much uniqueness. It is also never stale to write, so all people will be interested to discuss it. Through Liza of Lambeth, Maugham tries to explain the moral value beautifully and he 
reveals love which has a sense of tragic where finally the major character dies because of her fault in loving a married man.

This is the part which is planned to analyze. It is known that a person who takes a trmendous effort in reaching their dream will be success later. Uniquely, this novel is not like usual. Both Jim and Tom have showed their struggle to get Liza, and they have their own way in showing the efforts to have her. As a result, Jim is more successful than Tom, even though at the end of the story, Liza dies. It shows that people who make serious effort in their life is not guaranteed to have a success later.

Considering the explanation above, this article tries to find out an unstated idea from the author by analyzing the characterization of each character first and it will be a guidance to know the quality of the male characters' struggle in their effort to get Liza's love.

\section{REVIEW OF LITERATURE}

\subsection{Character}

Character, say Kennedy and Gioia, is ‘an imagined person who inhabits a story’ (2007:7). In this case, the writer uses the theory of character to analyze the personality descriptions of Liza, Jim, and Tom, which further can help the writer to explain about the quality of struggle between two male characters in the story in getting Liza's love. Furthermore, Kennedy and Gioia also explain that within the main character's self, there exhibits the human personalities familiar to the readers (2007:7).

\subsection{Existentialism Theory}

Existentialism forces one to talk about the essence of human in the world named freedom and choice. The main problem is then about the differences between human and things. The basic difference between human and thing is that human realizes its existence in the world and always asks about the meaning of their existence while thing does not. Soren Aabye Kierkegaard (1813-1855), a Danish philosopher and theologian, and also as a founder of existentialism says that existentialism is a compliance of each individual which is acquired from the freedom will (as cited in Howard, 2005 and in Suhartono, 2005:67).

For Kierkegaard, each person must have a certain involvement and commitment toward each event that he or she has experienced, so that person becomes an actor that plays a part in it. Principally, human has right and freedom to decide which one is true or false and which one is the best or the worst in their life. The human's reality outside may has a power to force or to influence them, but the decision to do something comes from the human itself. Related 
to freedom is responsibility, both of them are inseparable to each other (as cited in Howard, 2005 and in Suhartono, 2005:67).

The use of existentialism theory is believed by the writer to help her in finding out the characteristic of the male characters' struggle in the story. In this study, Jim and Tom have different characteristics in their struggle. Kierkegaard depicts three phases of human's existences called aesthetic phase, ethical phase, and religious phase (as cited in Abidin, 2006:148). 1). In aesthetic phase, human's orientation life is directed to get a pleasure. The aesthetic human lives for their personal happiness and interest (Abidin, 2006:148). 2). Meanwhile, in ethical phase, human begins to receive a moral righteousness and acts based on it. In this phase, human can control their action and adjust it with the universal morality standards (Hardiman, 2007:253). In the last phase, religious phase, it is a must for a human who wants to reach this phase to approve the transcendent subjectivity which only follows God's way. So, there is no rationalization in this phase (Abidin, 2006:151).

\subsection{Interpersonal Attraction}

theory of interpersonal attraction helps to find Liza's reasons in determining her attraction feeling toward the two male characters in the story. It is a theory that helps finding the causes which make someone is attracted to another one. There are four factors that underlie the interpersonal attraction: physical proximity, affective state, affiliation need, and observable characteristic (Baron and Byrne, 2006: 261).

\subsection{Deconstruction}

Deconstruction is a text reading method that is completely different with a reading method as usual. Deconstruction perusal tries to seek a failure of the text that sinks beneath the single truth (Norris, 2003:15). As what Derrida wants that a truth is not limited by singular, general, and universal truth. In fact, truth is plural, particular, and relative (as cited in Santoso, 2013:252). Briefly, what deconstruction wants is to awake the hidden power which also participates in building a text. Derrida also develops the notion of 'violent hierarchy', when one says that ' $a$ ' is prior to ' $b$ ', in fact ' $b$ ' is already implied in ' $a$ '. Thus the word 'good' implies the word 'evil', 'law' implies 'lawlessness' (as cited in Carter, 2006:110).

In Liza of Lambeth, violent hierarchy will explain about two male's qualities of struggle. In this case, between Jim and Tom who have fallen in love to the same girl named Liza. Both Jim and Tom have made some efforts to attract her with different ways. At last, Jim is the chosen man whom she loves until the end of her life. It indicates that the great struggle which has done by a man will not permanently get the same reward as the previous effort. 


\section{DISSCUSSION OF THE MAIN THEMES}

\subsection{Main Characters' Characterization in William Somerset Maugham's Liza of Lambeth}

Main character is an important character in a story that is appeared continually so that the main character dominates the story (Nurgiyantoro, 2010: 176). The main character in the story may be more than one characters but it is distinguished from the superiority degree of each main character. The superiority degree is determined by the story domination of the character and its influence toward the plot's development overall. So, there is a distinction in main character itself, those are main-main character and additional-main character (Nurgiyantoro, 2010:177-178).

In Liza of Lambeth, Liza and Jim are the main characters considering their domination in the story starting from the beginning, the middle, and the end of the story. Additionally, Liza and Jim influence the whole plot of the story. Meanwhile, Tom does not dominate too much in the story, but he can be classified as a main character because Tom is related with the main character, Liza. Besides, he also influences the plot development. Tom even shows Liza that there is a man who really loves her even when she is in her worst condition.

\section{Liza's Personality}

Liza Kemp in the story is depicted as a young beautiful girl who lives in Vere Street, Lambeth. Her beauty is successful in attracting many people, boys especially. Liza is not only a beautiful girl in her environment, but she also has a dancing talent which makes her become the most interesting girl among the others. Liza lives in Vere Street with her mother only, Mrs. Kemp.

Fatherless in her life indirectly has influenced Liza's life to be a strong girl because she must work by herself to earn money for surviving in the future even though her mother still gets a pension fund from her husband to fulfill their daily needs. She is also demanded not to be selfish because she has a mother whom she must take care of, whereas she is still eighteen. Fatherless in Liza's life has made her yearning for a figure of a man who can give her care and affection.

... and Liza, as she looked up at the heavens, felt a certain emotion, as if she wished to be taken in someone's arms, or feel some strong man's caress; and there was in her heart a strange sensation as though it were growing big (Maugham, 1897:35).

Liza is totally different when she faces sort of love in her life. She becomes an unprincipled girl because that is the first time Liza falls in love with a man. Her yearning for a man's affection finally is answered by Jim's presence. Liza, as an amateur girl in love, does not know what she must do. When Jim invites her to watch a play, Liza wants to come, but 
she realizes that Jim is a married man. She also considers about her neighbor's opinion if she really goes to watch the play with Jim. Eventually, Liza has decided that she will not come with Jim in the play. Then, when Liza meets Jim on the street, she gets angry to Jim because Jim does not mention about theatre at all. Liza thinks that Jim has forgotten about his invitation to Liza about the play. Actually, Liza should not get angry to Jim because she has told Jim that she will not come to the play, so Jim should not wait for her too and it is not Jim's fault about his absence in the play.

\section{Jim's Personality}

Jim is Liza's new neighbor on the Vere Street and he is a man with big body size. Jim is a married man who has five kids to look after. Although he has had a big family, but later he also becomes one of the men in Vere Street who wants to have Liza as a lover. Jim is sort of good listener, skillful man, and a brave man. Yet, Jim is not a soft man. He has even scolded Liza with an improper word when Liza rejects to go watching the play with him.

Jim's experience in love is really successful for making Liza feels the great love that she has never had once. It is known that his marriage has taught him to know how the way to make woman happy. On the contrary, the way Jim gets angry to his wife when she hurts Liza indicates that Jim is a selfish man. He does not think that what he has done is wrong. Their affair has hurt Mrs. Blakeston as his wife.

\section{Tom's Personality}

Tom is a single young man. He is one of the boys in Lambeth who loves Liza. As a single man, it makes Tom inexperienced to attract a girl's attention. Tom tries to approach Liza when they are in the brake on the way to Chingford by doing a physical contact. He does not know exactly how to get Liza's attention. When he tries to do it, he gets a rejection from Liza and it makes her angry to Tom.

Tom does fall in love with Liza, although he gets angry to Liza because Liza does not want to spend her time with Tom only. However, his love to Liza still dominates his feeling until he forgets that he has a fight with Liza a moment ago.

Although Tom cannot do anything to make Liza happy, he is sort of a kind man even when Liza has a fight with Jim's wife. He comes to help Liza and he leads her to get home. Actually, Tom has a choice not to help Liza because she has offended Tom's heart. 


\subsection{The Struggle Quality of Male Character's in William Somerset Maugham's Liza of Lambeth}

From those main characterizations, there will be a classification about the qualities of struggle between two male characters in Liza of Lambeth. The quality of struggle between Jim and Tom does not apart from some factors that have been explained in the review of literature.

\section{Jim's Struggle Quality to Get Liza}

Jim's struggle is started when he attempts to ask Liza to have a walk with him after the long journey from Chingford, but Liza refuses him. However, Jim does not stop to attract Liza more after his first meeting with her. For the second time Jim invites her to watch a play with him and Liza rejects his invitation realizing that Jim is a married man.

Besides Jim invites Liza to have a date with him, he also uses the way to express his love by saying it directly, 'Yer know, Liza, I love yer - fit ter kill.' (Maugham, 1897:53).

Jim's affair with Liza has met a climax. Jim wants Liza to live with him forever though Liza always refuses him considering that she cannot leave her mother. Moreover, it is a bigamy if Jim who has a wife and kids wants to marry Liza.

Having a date for many times with Liza, eventually the neighbors around them have known about their affair, including Jim's wife, Mrs. Blakeston. A fight between Jim's wife and Liza on the street is inescapable anymore. Jim comes to the crowd and finds that his wife and his lover are having a fight. Jim tries to make them apart, he is really angry with her wife. Jim's fearlessness to show his anger to his wife has proved that Jim tends to defend Liza than his own wife. Whereas, Liza is the one who must be blamed because of her clandestine affair with a married man.

Even when Liza is in worst health, Jim still has a bravery to come to her house. If Jim is not serious with Liza, he should be afraid to look at her because many people have known that Jim is ringleader of that fighting.

Jim's success in getting Liza's love also has some supporting factors that make him easier to fight for his love. For Liza, Jim has attractive traits that the other do not. In the first, Jim's physical appearance tends to be loved by Liza considering that her father is a soldier. Generally, a soldier is a big and strong man, and so is Jim. He has a great body and his beard also shows his masculinity. Being left by her father, it is possible for Liza to seek someone who has a father figure where she can feel safe and comfort. As what Benjamin Spock says that a child who does not have complete parents, a child tends to create a vivid description of the lost figure and girl more needs a father presence than boy (Spock, 1965). 
On the other hand, Jim has a physical proximity that can make him closer to Liza. Furthermore, from the affective state factor, it also supports Jim to get Liza. Liza is still recalling every moment that she spends together with Jim in Chingford though Liza and Jim are not as a couple yet. It is clear that Liza's affective state is very happy when she remembers Jim. Moreover, there is the last factor named affiliation need. Jim is also ready to have a further relationship with Liza. The relationship that has been built by Jim and Liza is in balance. There is no lame feeling between them. Both Jim and Liza love each other.

Nevertheless, as what Kierkegaard has depicted about three phases of human's existence, Jim's struggle that shows his existence to express his love to Liza while he has had a wife and kids belongs to aesthetic phase. In aesthetic phase, human's orientation is directed to fulfill their personal pleasure. By knowing Jim's struggle, it is clear that Jim only cares with his own happiness. In fact, Jim should know that his affair with Liza is wrong considering that he has had a family.

\section{Tom's Struggle Quality to Get Liza}

Despite Liza's preference for Jim, Tom does not surrender to get her. Tom's first struggle is expressed by saying a direct statement, such as I love you when he comes to Liza's house at the night. Tom has prepared everything to have Liza. He prepares either job or furniture for their future if Liza receives him. He even convinces Liza that he is not a drinking sort and he will be a good husband for her later, but Tom gets a rejection from her.

After Bank Holiday has passed, Tom supposes that Liza does not want to meet him, that she does not want Tom around her, so he restrains himself from her. Tom does not want to force Liza to love him.

Tom's struggle does not quit yet, even when Liza has been bullied by Jim's wife because Liza has an affair with her husband, Tom still attempts to ask Liza to marry him. Tom thinks that after Liza's fault by having a forbidden affair with a married man, and she gets many injuries from Jim's wife in her body as well as a social sanction from the society around her, Liza will change her mind to stay away from Jim and tries to receive Tom as her lover. On the contrary, Tom still gets a rejection from Liza after everything he has done for her.

Tom's struggle is completely different from Jim's struggle, though both Jim and Tom have got rejection from Liza once, but Tom is more unlucky than Jim. The cause is the factors that should help him to attract Liza's feeling. It does not work as perfect as in Jim's case. So, Tom does not have something to support his struggle. Start from the physical appearance, Liza cannot find her attractiveness to Tom because physically Tom tends to be a boy than a man. Furthermore, Tom does not have a physical proximity with Liza which it can be an 
access to get her. From the affective state, Tom's first coming in inviting Liza to have a walk with him is not in the right time. Liza has passed two different events before that influence her feeling to Tom. For the last is affiliation need, even though Liza knows Tom before Jim, but Liza does not have love for him.

According to the three phases of human's existence by Kierkegaard, Tom has been in the second phase that is ethical phase. If Tom is a selfish man, he will force Liza to love him. In reality, Tom does the opposite. He does not force Liza to receive him.

\subsection{Delineation of Deconstruction in William Somerset Maugham's Liza of Lambeth}

In this study, the writer tries to dismantle a single truth in grand narrative of William Somerset Maugham's Liza of Lambeth. For the first time, a reader will find a single meaning that this novel tells about a girl who makes a fault by loving a married man, and finally the girl gets a bad effect from her environment until she dies. On the contrary, by using deconstruction theory, there is a hidden meaning and it may be a truth which is not seen by the reader. Liza of Lambeth completely breaks the structureof the stereotype that all people who works hard will get what they want. It can be seen from the male characters in this novel, they are Jim and Tom. Both of them have fought to get a girl's love named Liza, though they have different ways to express their love. As a result, both of Jim and Tom cannot have Liza as their lover forever because her death comes before one of them can marry her. However, Jim still be the winner of Liza's heart, while Tom must admit his shellacking.

It is also supported by an England Journalist, Woodrow Wyatt in Howard Friedman who says that a man falls in love through his eyes, and woman falls in love through her ears (140). Man tends to be attracted to woman because of woman's beauty. It is seen that both Jim and Tom love Liza because of her physical appearance. From an Islamic value itself, there is a hadith from Muslim about a man who wants to get marry which states that "From Abu Hurairah RA, Prophet Muhammad SAW utters 'Woman is married because of four matters; the first is because of her wealth, generation, beauty, and for her religion. So, choose the woman because of her religion, you will be lucky and happy' (Muslim)" (Nashiruddin AlAbani).

It is clear that Islamic value also emphasizes that woman's physical appearance belongs to one of four considerations that have been considered for a man who wants to get marry, apart from the other one. 


\section{CONCLUSION}

The result of this study shows that both Jim and Tom try to get Liza's attention. They have a different quality of struggle in winning Liza. According to the phases of human's existence by Kierkegaard, Jim's struggle quality is in the first phase, aesthetic phase. Jim fulfills his own pleasure without thinking about the moral value in his environment. He loves Liza, whereas he has a wife and kids to look after. Meanwhile, Tom's struggle quality is higher than Jim because Tom has been in the second phase, ethical phase. Tom knows that he loves Liza, but he decides to fight for Liza with his own way that is without forcing his love to Liza.

Besides that, there are some factors which support their struggle to attract Liza. Liza is more attracted to Jim because he has a figure that Liza seeks. Liza is fatherless, that is why Liza tends to seek a man who can give her a sense of protection. Liza finds it in Jim, moreover Liza and Jim have physical proximity that makes them can meet easily and build a deeper relationship. As a result, Liza and Jim are getting closer and they love each other. While in Tom, Liza does not find any attractiveness to him. Tom's physical appearance tends to be boyish than a man. Tom also does not have a physical proximity which can help him to meet Liza many times. So that, he is difficult to create a communication and he fails to make Liza becomes closer with him.

\section{REFERENCES}

Abidin, Z. (2006). Filsafat manusia. Bandung: Rosda.

Al-Abani, N. (2009). Mukhtashar shahih muslim. Retrieved from http://kampungsunnah.org/\#

Baron, R. A. and Byrne, D. (2004). Psikologi Sosial. Jakarta: Erlangga.

Carter, D. (2006). Literary Theory. Great Britain: Cox and Wyman Reading.

Friedman, H. S. (2008). Kepribadian: Teori Klasik dan Riset Modern. Jakarta: Erlangga.

Hardiman, F. B. (2007). Filsafat Modern. Jakarta: Gramedia Pustaka Umum.

Howard, A. (2005). Konseling dan Psikoterapi Cara Filsafat. Jakarta: Teraju.

Kennedy, X.J. and Gioia, D. (2007). Literature: An Introduction to Fiction, Poetry, Drama, and Writing. Tenth Edition. New York: Pearson Longman.

Maugham, W.S. (1897). Liza of Lambeth. Harmondsworth, UK: Penguin.

Norris, C. (2003). Membongkar Teori Dekonstruksi Jacques Derrida. Yogyakarta: Ar-Ruzz. 
Nurgiyantoro, B. (2010). Teori Pengkajian Fiksi. Yogyakarta: UGM Press.

Santoso, L. (2013). Epistemologi Kiri. Yogyakarta: Ar-Ruzz Media.

Spock, B. (1965). Problems of Parents. New York: Fawcett World Library.

Stevenson, L. (1967). The History of the English Novel. New York: Barnes and Noble.

Suhartono, S. (2005). Sejarah Pemikiran Filsafat Modern. Yogyakarta: Ar- Ruzz 